\title{
The in vitro Antimycotic Activity and Acute Toxicity of Third-Generation Bezylidenetetralones and Heteroarylidenetetralones
}

\author{
Tahsin M. Al-Nakib a Tamás Lóránd ${ }^{\mathrm{b}}$ András Földesic ${ }^{\mathrm{C}}$ Ramani Varghese $^{\mathrm{a}}$ \\ aDepartment of Pharmacology and Toxicology, Faculty of Medicine, Health Science Centre, Kuwait University, \\ Kuwait; ${ }^{b}$ Department of Medical Chemistry, Faculty of Medicine, and ' ${ }^{\mathrm{D}}$ Department of Analytical Chemistry, \\ Faculty of Science, University of Pécs, Hungary
}

\section{Key Words}

Benzylidenetetralones · Heteroarylidenetetralones •

Antimycotic activity, in vitro - Acute toxicity, in vivo/in vitro

\begin{abstract}
Objectives: A new series of E-2-arylmethylene-1-tetralones and E-2-heteroarylmethylene-1-tetralones (third generation) were designed as potential antimycotic agents against human pathogenic yeasts. Methods: The new compounds were obtained by aldol condensation of 1-tetralone with the appropriately substituted aldehydes in either acid- or base-catalysed conditions. These compounds were tested for their in vitro antimycotic activity against 24 strains of Cryptococcus neoformans, Candida spp. and Trichosporon cutaneum by a microtitre well technique in a liquid casitone medium, using a double dilution method. The toxicity of the new compounds was determined in vitro in cultured HeLa cells, in HeLa growth medium and in vivo in MFI mice. Results: Nineteen new E-2-benzylidine-1-tetralones were prepared, and 16 of the tested compounds showed superior antimycotic activity when compared to the first-genera-
\end{abstract}

tion E-2-benzylidine-1-tetralones synthesised previously. Twelve of these third-generation compounds were more active against different strains of yeasts than 6 commercial antimycotic agents similarly tested. An in vitro toxicity study and an in vivo acute toxicity study in MFI mice showed that these compounds were severalfold less toxic than most of the commerical antimycotics, with 4 being comparable to or less toxic than the least toxic of the commercial agents (amphotericin B) tested by the same procedures. Conclusions: Twelve members of this new E-2-benzylidine-1-tetralone class of compounds are promising candidates for antimycotic agents worthy of further investigation.

Copyright $@ 2001$ S. Karger AG, Basel

\section{Introduction}

We have previously reported the aldol condensation of 1-tetralones with appropriately substituted aldehydes in the presence of weak bases such as piperidine or pyrrolidine, which were shown to yield E-2-benzylidene derivatives at room temperature [1-5]. Although these first-generation E-2-benzylidene-1-tetralones were shown to ex-

\begin{tabular}{ll}
\hline KARGER & ( ) 2001 S. Karger AG, Basel \\
1011-7571/01/0104-0191\$17.50/0 \\
$\begin{array}{l}\text { Fax +4161306 12 34 } \\
\text { Eww.karger.com }\end{array}$ & $\begin{array}{l}\text { Accessible online at: } \\
\text { www.karger.com/journals/mpp }\end{array}$
\end{tabular}

Tamás Lóránd, $\mathrm{PhD}$

Department of Medical Chemistry

Faculty of Medicine, Pécs University, Szigeti ut 12

H-7624 Pécs (Hungary)

Tel. +36 72536 224/1863, Fax +36 72536 225, E-Mail tamas.lorandt@aok.pte.hu 
<smiles>[R]c1cc([R])c(/C=C2\CCc3ccccc3C2=O)c([R])c1[Y]</smiles><smiles>O=C1C(=CBr)CCc2ccccc21</smiles>

Fig. 1. Structure of the 19 new compounds, with aryl or heteroaryl groups.

Table 1. Substitution pattern of the 19 E-2-benzylidene-1-tetralone analogues synthesised

\begin{tabular}{rlllll}
\hline $\begin{array}{l}\text { Com- } \\
\text { pound }\end{array}$ & Aryl & $\mathrm{R}_{1}$ & $\mathrm{R}_{2}$ & $\mathrm{R}_{3}$ & $\mathrm{R}_{4}$ \\
\hline 1 & - & & & & \\
2 & - & $\mathrm{H}$ & $\mathrm{OCH}_{2} \mathrm{Ph}$ & $\mathrm{H}$ & $\mathrm{H}$ \\
3 & - & $\mathrm{H}$ & $\mathrm{H}$ & $\mathrm{COOH}$ & $\mathrm{H}$ \\
4 & - & $\mathrm{H}$ & $\mathrm{OSO}_{2} \mathrm{CH}_{3}$ & $\mathrm{H}$ & $\mathrm{H}$ \\
5 & - & $\mathrm{SO}_{3} \mathrm{H}$ & $\mathrm{H}$ & $\mathrm{H}$ & $\mathrm{H}$ \\
6 & - & $\mathrm{OCH}_{3}$ & $\mathrm{H}$ & $\mathrm{H}$ & $\mathrm{H}$ \\
7 & - & $\mathrm{H}$ & $\mathrm{O}\left(\mathrm{CH}_{2}\right)_{3} \mathrm{CH}_{3}$ & $\mathrm{H}$ & $\mathrm{H}$ \\
8 & - & $\mathrm{H}$ & $\mathrm{OH}$ & $\mathrm{H}$ & $\mathrm{H}$ \\
9 & - & $\mathrm{Cl}$ & $\mathrm{H}$ & $\mathrm{H}$ & $\mathrm{H}$ \\
10 & - & $\mathrm{H}$ & $\mathrm{Cl}$ & $\mathrm{Cl}$ & $\mathrm{H}$ \\
11 & - & $\mathrm{Cl}$ & $\mathrm{H}$ & $\mathrm{Cl}$ & $\mathrm{H}$ \\
12 & - & $\mathrm{Cl}$ & $\mathrm{H}$ & $\mathrm{H}$ & $\mathrm{Cl}$ \\
13 & 2'-(1'-N-methyl)- & $\mathrm{H}$ & $\mathrm{CN}$ & $\mathrm{H}$ \\
& pyrrolyl & & & & \\
14 & 2'-pyridyl & & & & \\
15 & 2'-thienyl & & & & \\
16 & 3'-pyridyl & & & & \\
17 & 4'-pyridyl & & & & \\
18 & 2'-furyl & & & & \\
19 & 2'-pyrrolyl & & & & \\
\hline
\end{tabular}

hibit very low toxicity in vivo [3], their in vitro activity against some pathogenic yeasts was found to be discouraging [2-4]. When the new aldol condensation, performed in ethanolic sodium hydroxide at $0^{\circ} \mathrm{C}$, was utilised to synthesise another generation of E-2-benzylidine- or E-2-het- eroarylidene-1-tetralones (compounds $1-12$ or $13-19$, respectively), the condensation products obtained also had the E configuration (fig. 1). Carrying out the condensation with prolonged heating under acidic conditions with orthophosphoric acid (at $80^{\circ} \mathrm{C}$ ) also exclusively yielded the E-2-arylidene derivatives (fig. 1). Using these two newer reaction conditions, 19 new compounds were synthesised having a variety of aryl or heteroaryl groups (fig. 1; table 1).

The antimycotic activity of these new compounds was assessed in vitro using a microtitre technique, against 24 strains of Cryptococcus neoformans, Candida spp. and Trichosporon cutaneum, and compared to that of $6 \mathrm{com}-$ mercially available antimycotic agents tested simultaneously [2-6].

The toxicities of the compounds prepared were investigated both in vitro in a HeLa cell line [7, 8] as well as by an acute toxicity procedure in MFI mice [3, 7-9], and the results were compared with those of 6 commercial antimycotic agents, tested similarly.

\section{Materials and Methods}

A general base-catalysed method for the synthesis of the E-2-arylidene-1-tetralones (1-19) was used. 1-Tetralone $(0.01 \mathrm{~mol})$ and the corresponding aldehyde $(0.01 \mathrm{~mol})$ were dissolved in ethanol $(150 \mathrm{ml})$, and sodium hydroxide solution $(30 \mathrm{ml}, 6.7 \mathrm{M})$ was added to the reaction mixture at $4{ }^{\circ} \mathrm{C}$. The separated crystals were filtered, washed with cold ethanol and distilled water until the $\mathrm{pH}$ of the wash-out was neutral.

A general acid-catalysed method for the synthesis of the E-2-arylidene-1-tetralones (1-19) was also used. 1-Tetralone $(0.01 \mathrm{ml})$ and the appropriate adlehyde $(0.01 \mathrm{~mol})$ were dissolved in phosphoric acid $(85 \%, 25 \mathrm{ml})$. The reaction mixture was stirred under argon atmosphere in an oil bath at $80^{\circ} \mathrm{C}$ for $6 \mathrm{~h}$, cooled to ambient temperature and diluted with water. The oily solution was extracted several times with chloroform $(3 \times 100 \mathrm{ml})$, and the combined chloroform extracts were washed with water until the wash-out became neutral. The extract was dried on anhydrous magnesium sulphate. The products obtained by both the base- and acid-catalysed procedures were found to be identical by chemical characterisation as described below.

The newly synthesised compounds $1-19$ were obtained in moderate to high yields (21-99\%). The products were recrystallised from methanol. Some of them required further purification by silica gel column chromatography using the eluents benzene for 1 , benzeneacetone $(40: 1 \mathrm{v} / \mathrm{v})$ for 3 and benzene-hexane $(9: 1 \mathrm{v} / \mathrm{v})$ for 6 . Their physical data, listed in table 2 , were in accordance with the analogous compounds published elsewhere [10] or - for compounds 13, 15 and 18 - were found to be identical with those reported previously [11]. The pure compounds were characterised by NMR and infrared spectroscopic methods and elemental analysis. In particular, the appearance of the $\mathrm{H}-\alpha$ proton signal in the range of $\delta 8.50-7.60 \mathrm{ppm}$ in the ${ }^{1} \mathrm{H}-\mathrm{NMR}$ spectra unequivocally corroborated their E configuration $[12,13]$. 
For in vitro antimycotic activity, the compounds were dissolved in DMSO (analar), and the activity was tested by a microtitre well technique in triplicate sets, in a liquid casitone medium. A double dilution method within the concentration range of $0.8-100 \mu \mathrm{g} / \mathrm{ml}$ was used against 24 strains of $C$. neoformans, Candida spp. and $T$. cutaneum, employing the procedure reported earlier [2-4, 7]. The cells which were originally hospital isolates from different hospitals in Kuwait and Ireland were maintained by routine subculture on subaroid solid media and were classified using conventional methods $[2,4,14]$. The level of DMSO in any well did not exceed $2.5 \%(\mathrm{v} / \mathrm{v})$, which was found to be non-inhibitory to fungal growth in control wells $[2-4,7]$. For assessment of the level of the antimycotic activity of the compounds prepared in this investigation, 6 commercial antimycotic agents were also tested simultaneously using the same experimental conditions. The commercial agents were: miconazole, isoconazole, sertaconazole, amphotericin B, haloprogin and tolnaftate. Compounds exhibiting minimum inhibitory concentration (MIC) values of $6 \mu \mathrm{g} / \mathrm{ml}$ or lower were considered to display good antimycotic activity.

The toxicities of the new compounds and the references compounds listed above were determined in vitro in cultured HeLa cells (Ohio) and in a HeLa growth medium $[14,15]$ in triplicate sets at each concentration over a concentration range of $1-500 \mu \mathrm{g} / \mathrm{ml}$ per culture bottle. The cells in each culture bottle were harvested and counted using a haemocytometer. The survival of the cells in the culture bottles was expressed as a percentage of the control culture cells (without any added compound or agent). A two-tailed Anova model in SPSS for Windows (version 6.1.1) was used for statistical analysis. The values of the inhibitory concentrations $\left(\mathrm{IC}_{50} ; \mu \mathrm{g} / \mathrm{ml}\right)$ were then determined from the graph for each compound or agent, as described earlier by us $[6,7]$.

The in vivo toxicity of the compounds $1-19$ compared to the 6 commercial agents was assessed in triplicate sets of 10 MFI mice using an acute toxicity procedure $[9,15]$. The $\mathrm{LD}_{50}$ values were considered valid for any group of mice, per compound or agent, when the survival coefficient of variance for the particular dose used was within $3-5 \%[6,9]$.

\section{Results}

A list of the 19 compounds synthesised and the substitution pattern are shown in table 1 . Their physical data are listed in table 2. The MIC values for active compounds $(6 \mu \mathrm{g} / \mathrm{ml}$ or lower) as a measure of their in vitro antimycotic activity, and those of the 6 commercial antimycotic agents $(12.5 \mu \mathrm{g} / \mathrm{ml}$ or lower) against the 24 strains of yeasts tested, are shown in table 3 .

The inhibitory concentrations for each compound or agent determined by in vitro toxicity testing in HeLa cell lines and calculated from the mean survival counts' curves for each compound or agent using the SPSS package are listed in table 4 . The $\mathrm{LD}_{50}$ values for compounds 1-19 and the 6 commercial agents ( $\mathrm{mg} / \mathrm{kg}$ weight) provide a measure of their in vivo toxicity in MFI mice (table 4).
Table 2. Physical data for compounds 1-19

\begin{tabular}{lcll}
\hline Compound & $\begin{array}{l}\text { Melting point } \\
{ }^{\circ} \mathrm{C}\end{array}$ & $\begin{array}{l}\text { Yield } \\
\%\end{array}$ & $\begin{array}{l}\text { Molecular } \\
\text { formula }\end{array}$ \\
\hline 1 & $45-46$ & $80^{1}$ & $\mathrm{C}_{24} \mathrm{H}_{20} \mathrm{O}_{2}$ \\
2 & $240-242$ & 99 & $\mathrm{C}_{18} \mathrm{H}_{14} \mathrm{O}_{2}$ \\
3 & $95-97$ & $22^{2}$ & $\mathrm{C}_{18} \mathrm{H}_{16} \mathrm{O}_{4} \mathrm{~S}$ \\
4 & 149 (dec.) & 21 & $\mathrm{C}_{17} \mathrm{H}_{14} \mathrm{O}_{3} \mathrm{~S}$ \\
5 & $109-111$ & 80 & $\mathrm{C}_{18} \mathrm{H}_{16} \mathrm{O}_{2}$ \\
6 & -3 & 374 & $\mathrm{C}_{21} \mathrm{H}_{22} \mathrm{O}_{2}$ \\
7 & $152-153$ & 40 & $\mathrm{C}_{17} \mathrm{H}_{14} \mathrm{O}_{2}$ \\
8 & $73-74$ & 86 & $\mathrm{C}_{17} \mathrm{H}_{13} \mathrm{ClO}$ \\
9 & $152-154$ & 63 & $\mathrm{C}_{17} \mathrm{H}_{12} \mathrm{Cl}{ }_{2} \mathrm{O}$ \\
10 & $108-109$ & 90 & $\mathrm{C}_{17} \mathrm{H}_{12} \mathrm{Cl}{ }_{2} \mathrm{O}$ \\
11 & $66-67$ & 40 & $\mathrm{C}_{17} \mathrm{H}_{12} \mathrm{Cl}{ }_{2} \mathrm{O}$ \\
12 & $162-163$ & 77 & $\mathrm{C}_{18} \mathrm{H}_{13} \mathrm{ON}$ \\
14 & $122-123$ & 30 & $\mathrm{C}_{16} \mathrm{H}_{13} \mathrm{NO}$ \\
16 & $75-76$ & 32 & $\mathrm{C}_{16} \mathrm{H}_{13} \mathrm{NO}$ \\
17 & $114-115$ & 59 & $\mathrm{C}_{16} \mathrm{H}_{13} \mathrm{NO}$ \\
19 & $180-182$ & 63 & $\mathrm{C}_{15} \mathrm{H}_{13} \mathrm{NO}$ \\
\hline
\end{tabular}

dec. $=$ Decomposition

$1 \quad 19 \%$ of starting material was recovered.

$271 \%$ of starting material was recovered.

Oily compound.

$40 \%$ of starting material was recovered.

\section{Discussion}

Nineteen members of this third generation of E-2-benzylidene-1-tetralones (table 1) were synthesised under the new strong acid and base reaction conditions as we intended to introduce heteroaromatic compounds (1319), polychlorinated (9-11), ionisable hydroxyl sulphonic and acidic groups $[2,4,7]$ as well as new ether, ester $(1,3$, $5,6)$ and cyano (12) residues as substituents for comparison to the first and second generation 1-4 and 14 E-2benzylidene-1-tetralones, respectively. The broad spectrum of antimycotic activity exhibited by 10 of the new compounds (table 3 ) was generally dependent on the presence of free or ionisable acidic-oxygenated functional groups $(2,4,7)$ or nitrogenous residues having free or nonmethylated nitrogen atoms, and specifically when the nitrogen substituent was a 6-membered ring (pyridyl derivatives; $14,16,17)$ and, to a lesser extent, when the nitrogen residue was that of a 5-membered pyrrole ring (19).

Masking of either the free oxygen or the nitrogen atoms $(1,6,13)$ resulted in the loss of activity, except in the case of the mesyloxy compound (3), which was shown to be 
Table 3. The MIC ( $\mu \mathrm{g} / \mathrm{ml})$ values of the active E-2-benzylidene-1-tetralone analogues and commercial agents, against 24 strains of yeasts

\begin{tabular}{lll}
\hline $\begin{array}{l}\text { Yeast } \\
\text { tested }\end{array}$ & Active compounds ${ }^{1}$ & Commercial agents $^{2}$ \\
\hline
\end{tabular}

Cryptococcus neoformans

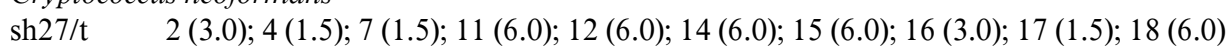

$\mathrm{A}(12.5) ; \mathrm{H}(12.5) ; \mathrm{S}(12.5)$

ah27/a 2(3.0); $4(0.8) ; 7(1.5) ; 11(6.0) ; 12(6.0) ; 14(6.0) ; 15(6.0) ; 16(6.0) ; 17(1.5) ; 18(6.0)$

$\mathrm{A}(12.5) ; \mathrm{H}(12.5) ; \mathrm{T}(12.5) ; \mathrm{S}(12.5)$

ahh $1 / \mathrm{j} \quad 2(3.0) ; 4(1.5) ; 7(1.5) ; 14(6.0) ; 15(6.0) ; 16(6.0) ; 17(1.5)$

ahh9/r 2(3.0); $4(1.5) ; 7(1.5) ; 11(6.0) ; 14(6.0) ; 15(6.0) ; 16(6.0) ; 17(3.0) ; 18(6.0)$

$\mathrm{mk} 53 / \mathrm{k} \quad 2(6.0) ; 4(1.5) ; 7(3.0) ; 12(6.0) ; 16(3.0) ; 17(3.0)$

ahh $2 / \mathrm{n} \quad 2(6.0) ; 4(1.5) ; 7(1.5) ; 12(6.0) ; 16(3.0) ; 17(1.5)$

$\mathrm{A}(6) ; \mathrm{H}(12.5) ; \mathrm{T}(12.5) ; \mathrm{S}(12.5)$

$\mathrm{A}(12.5) ; \mathrm{H}(12.5) ; \mathrm{S}(6.0)$

A (12.5); H (12.5); S (6.0)

Candida albicans

$\mathrm{am} / \mathrm{t} 27 \quad 3(6.0) ; 7(6.0) ; 11(6.0)$

$\mathrm{sh} / \mathrm{t} 54 \quad 3(6.0) ; 7(6.0) ; 11(6.0) ; 14(6.0) ; 17(6.0)$

$\mathrm{mk} / \mathrm{b} 65 \quad 3(6.0) ; 7(6.0) ; 17(6.0)$

$\mathrm{H}(6) ; \mathrm{S}(12.5)$

$\mathrm{jg} / \mathrm{j} 68 \quad-$

tc/d92 $3(6.0) ; 7(6.0) ; 11(6.0)$

$\mathrm{lm} / \mathrm{s} 93 \quad 3(6.0) ; 11(6.0)$

$\mathrm{A}(12.5) ; \mathrm{H}(12.5) ; \mathrm{S}(12.5)$

A (12.5); H (12.5); S (12.5)

$\mathrm{H}$ ( 12.5); S (6.0)

$\mathrm{S}(6.0)$

A (12.5); H (12.5); S (12.5)

Candida parapsilosis

$\mathrm{ah} / \mathrm{t} 42 \quad 3(6.0) ; 7(6.0) ; 10(6.0) ; 14(6.0) ; 18(6.0)$

$\mathrm{mk} / \mathrm{j} 68 \quad 3(6.0) ; 9(6.0) ; 19(6.0) ; 18(6.0)$

$\mathrm{jg} / \mathrm{j} 69 \quad 3(6.0) ; 9(6.0) ; 14(6.0) ; 18(6.0)$

$\mathrm{H}(12.5) ; \mathrm{S}(12.5)$

\section{Candida tropicalis}

cp/k92 $11(6.0) ; 17(3.0) ; 18(3.0)$

$\mathrm{cp} / \mathrm{k} 91 \quad 11(6.0) ; 17(3.0) ; 18(1.5)$

$\mathrm{cp} / \mathrm{v} 91 \quad 11(6.0) ; 17(3.0) ; 18(1.5)$

$\mathrm{A}(12.5) ; \mathrm{H}(6.0) ; \mathrm{T}(12.5) ; \mathrm{S}(12.5)$

$\mathrm{H}(12.5) ; \mathrm{T}(12.5) ; \mathrm{S}(6.0)$

A (12.5); H (12.5); S (6.0)

\section{Candida glabrata}

t/92k $3(6.0) ; 9(6.0) ; 14(6.0) ; 15(3.0) ; 19(6.0)$

$\mathrm{t} / 91 \mathrm{k} \quad 3(3.0) ; 9(6.0) ; 14(6.0) ; 15(3.0) ; 19(6.0)$

A (12.5); H (12.5); T (12.5); S (6.0)

$\mathrm{A}(6) ; \mathrm{H}(12.5) ; \mathrm{S}(12.5)$

A (12.5); H (6); S (6.0)

$\mathrm{k} / 92 \mathrm{j} \quad 3(3.0) ; 5(6.0) ; 14(6.0) ; 15(3.0) ; 19(6.0)$

A (6); H (6); S (12.5)

A (12.5); H (12.5); T (6); S (12.5)

A (12.5); H (6); T (12.5); S (6.0)

Trichosporon cutaneum

cw/92 $7(6.0) ; 9(3.0) ; 12(3.0) ; 14(6.0) ; 15(6.0) ; 17(3.0)$

$\mathrm{jk} / 92 \quad 7(6.0) ; 9(1.5) ; 12(3.0) ; 14(3.0) ; 15(6.0) ; 17(3.0)$

$\mathrm{A}(6.0) ; \mathrm{H}$ (12.5); T (12.5); S (6.0)

A (12.5); H (6); T (12.5); S (6.0)

$\mathrm{vx} / 91 \quad 7(6.0) ; 9(3.0) ; 12(3.0) ; 14(3.0) ; 15(6.0) ; 17(6.0)$

A (12.5); H (12.5); T (12.5); S (12.5)

MIC values determined in vitro in liquid casitone medium. $\mathrm{A}=$ Amphotericin $\mathrm{B} ; \mathrm{H}=$ haloprogin; $\mathrm{T}=$ tolnaftate; $\mathrm{S}=$ sertaconazole.

1 Compound numbers are accompanied by their MIC values $(\mu \mathrm{g} / \mathrm{ml})$ in parentheses. Compounds with a MIC of $6 \mu \mathrm{g} / \mathrm{ml}$ or lower are considered to reflect good antimycotic activity.

2 MIC values greater than $12.5 \mu \mathrm{g} / \mathrm{ml}$ for commercial agents are not quoted, those of $12.5 \mu \mathrm{g} / \mathrm{ml}$ or lower are shown in parentheses.

active against $C$. albicans, $C$. parapsilosis and C. glabrata strains only. The most active commercial agents tested were sertaconazole and amphotericin $\mathrm{B}$, exhibiting good activity in the majority of the strains (MIC values of 12.5 or $6 \mu \mathrm{g} / \mathrm{ml})$. None of the compounds was active against the $C$. albicans strain $(\mathrm{jg} / \mathrm{j} 68)$, where only sertaconazole of the commercial agents exhibited good activity.

Although the simple E-2-benzylidine-1-tetralones (112) were overall less toxic than those where the phenyl group was replaced with a heterocyclic moiety (13-19), as reflected by their $\mathrm{LD}_{50}$ values in mice, many were comparably or slightly more toxic than the least toxic commercial agent, amphotericin B. When compared to the most active of the commercial agents, sertaconazole, the in vivo toxicity of the new compounds was found to be marginally better. In particular, those compounds with carboxyl (2) and mesyloxy substituents (3) were about 11 and 6\% less toxic than sertaconazole. The toxicity differences between those for amphotericin B and sertaconazole relative to the compounds 1-19 were more amplified in cell 
Table 4. In vivo and in vitro toxicity for the 19 new E-2-benzylidene1-tetralone analogues and the 6 commercial antimycotic agents tested

\begin{tabular}{|c|c|c|c|}
\hline & $\begin{array}{l}\text { In vivo } \mathrm{LD}_{50} \\
\mathrm{mg} / \mathrm{kg}\end{array}$ & $\begin{array}{l}\text { In vitro } \mathrm{IC}_{50} \\
\mu \mathrm{g} / \mathrm{ml}\end{array}$ & $\mathrm{p}$ value \\
\hline \multicolumn{4}{|c|}{ Compound } \\
\hline 1 & $>350$ & 291.4 & 0.001 \\
\hline 2 & 256 & 199.5 & 0.001 \\
\hline 3 & 242 & 215.5 & 0.001 \\
\hline 4 & 165 & 106.9 & 0.001 \\
\hline 5 & 179 & 90.4 & 0.012 \\
\hline 6 & $>350$ & 263.1 & 0.001 \\
\hline 7 & 183 & 82.2 & 0.008 \\
\hline 8 & 236 & 120.1 & 0.030 \\
\hline 9 & 212 & 153.2 & 0.001 \\
\hline 10 & 209 & 147.2 & 0.001 \\
\hline 11 & 216 & 156.5 & 0.041 \\
\hline 12 & 198 & 122.3 & 0.001 \\
\hline 13 & 152 & 81.4 & 0.038 \\
\hline 14 & 163 & 84.4 & 0.007 \\
\hline 15 & 138 & 61.4 & 0.008 \\
\hline 16 & 145 & 72.8 & 0.022 \\
\hline 17 & 131 & 52.9 & 0.046 \\
\hline 18 & 103 & 30.9 & 0.048 \\
\hline 19 & 129 & 43.6 & 0.008 \\
\hline \multicolumn{4}{|c|}{ Commercial agent } \\
\hline M & 220 & 18.8 & 0.002 \\
\hline I & 189 & 21.8 & 0.018 \\
\hline $\mathrm{H}$ & 89 & 5.2 & 0.005 \\
\hline $\mathrm{T}$ & 120 & 7.6 & 0.016 \\
\hline A & 260 & 36.4 & 0.014 \\
\hline S & 228 & 14.9 & 0.008 \\
\hline
\end{tabular}

$\mathrm{p}$ values were obtained from mean cell counts at different concentrations for each compound or commercial agent in test culture flasks, as a percentage of control culture flasks where neither compounds nor agents were added. $\mathrm{M}=$ Miconazole; $\mathrm{I}=$ isoconazole; $\mathrm{H}=$ haloprogin; $\mathrm{T}=$ tolnaftate; $\mathrm{A}=$ amphotericin $\mathrm{B} ; \mathrm{S}=$ sertaconazole . culture, where all 10 active compounds $(2,4,7,9,11,12$, $14,16,17,19)$ were found to be 5 - to 15 -fold less toxic than either of the 2 commercial agents described above.

The 2 most non-toxic compounds, either in vitro or in vivo, in the series were compounds 1 and 6 . Unfortunately these 2 compounds exhibited weak antimycotic activity against the strains utilised in this study.

The mechanism of action of other $\alpha, \beta$-unsaturated ketones has been studied by Dimmock and Wong [16], and it is suggested that it is due to the alkylation of the thiol enzymes. Although the mechanism of action of these third-generation compounds has not been studied, we speculate that their activity would decrease in the presence of such thiols as thioglycolic acid, cysteine and glutathione.

\section{Conclusion}

We have synthesised 19 E-2-arylidene-1-teralones that displayed in vitro antimycotic activity against 24 miconazole-resistant fungi. The compounds of highest activity contain ionisable oxygenated functional groups or basic groups with unsubstituted cyclic nitrogen atoms.

\section{Acknowledgement}

The statistical advice and help of Dr. Premnath Sharma of the Health Sciences Center Computer Department, Faculty of Medicine, Kuwait University, in dealing with the SPSS-PC package which was utilised in data treatment, is acknowledged with thanks. Some of the materials used in this study were originally purchased from the Kuwait Foundation for the Advancement of Science (KFAS) grant (96-07-11), awarded to T.M.A.N., and for this it is duly acknowledged with gratitude.

\section{References}

1 Al-Nakib TM: Studies in the Synthesis and Chemistry of Fungitoxic Benzofuro [3, 2-c]benzopyrans and 3-Benzylidenechroman-4-ones; dissertation, University of Dublin, 1984, pp 210-285.

2 Al-Nakib TM, Bezjak V, Meegan MJ, Chandy $\mathrm{R}$ : Synthesis and antifungal activity of some 3-benzylidenechroman-4-ones, 3-benzylidenethiochroman-4-ones and 2-benzylidene-1-tetralones. Eur J Med Chem 1990;25:455-462.
3 Al-Nakib TM, Miller NJ, Rashid S, Meegan MJ: An evaluation of the acute in vivo toxicity of benzylidenechroman-4-ones, 1-thiobenzylidenechroman-4-ones and benzylidenetetralones. Drug Chem Toxicol 1990;13:195-207.

4 Al-Nakib TM, Bezjak V, Rashid S, Meegan MJ: Structure-to-antimycotic activity of benzylidenechromanones against 6 miconazole-resistant yeasts in vitro. Med Principles Pract 1990; 2:100-105

5 Al-Nakib TM, Tyndall DV, Meegan MJ: The synthesis of [1]benzopyrano[4,3-b]pyridines and pyrano[3,2-c]benzopyrans. J Chem Res 1987; 10:2743-2772.
6 Al-Nakib TM, Perjesi P, Varghese R, Meegan MJ: Benzylideneindanones and benzylidenebenzosuberones: Relationship between structure, antimycotic activity and acute toxicity. Med Principles Pract 1997;6:14-21.

7 Boggust WA, Al-Nakib TM: The effect of monoamine oxidase inhibitors on the regulation of tumour growth by monoacetyl-putrescine and putrescine. IRCS Med Sci 1985;13: 245-246. 
8 Boggust WA, Al-Nakib TM: Promotion and suppression of tumour growth and cell proliferation by acetylputrescine and putrescine and their oxidation products acetyl-GABA and GABA. IRCS Med Sci 1986;14:174-175.

9 Jones LM, Booth NH, McDonald LE: Veterinary Pharmacology and Therapeutics, ed 4 Ames, Iowa State University Press, 1977, pp 156-158.

10 Orlov VD, Borovoi IA, Surov YN, Lavrushin VF: Proton-acceptor capacity and electronic absorption spectra of arylidene derivatives or indanone, tetralone and chromanone. $\mathrm{Zh}$ Obsch Khim 1976;46:2138-2147.
11 Rayes NR, Al-Jawhary A: Heterocycles. VIII. Synthesis of new substituted Benz[g]indazoles. J Heterocyclic Chem 1986;23:135-140.

12 Gottlieb HE: NMR spectroscopy of enones; in Patai S, Rappoport Z (eds). The Chemistry of Enones. Chichester, Wiley, 1989, vol 1, pp 9697.

13 Kevill DN, Weiler ED, Cromwell NH: cis-trans isomerism of exocyclic $\alpha, \beta$-unsaturated indanones and tetralones. J Org Chem 1970;29: 1276-1278.
14 Lodder EW: General classification of the yeast; in Lodder EW (ed): The Yeasts: A Taxonomic Study, ed 3. Amsterdam, North-Holland, 1974, pp 1-33.

15 Al-Nakib TM, Abu-Lisan M, Al-Johari G, Meegan MJ: Antimycotic activity and acute toxicitiy of benzopyranopyrans and related compounds. Med Principles Pract 1990-91;2: 221-227.

16 Dimmock JR, Wong MLC: Bioactivities and potential uses in drug design of acyclic $\alpha, \beta$ unsaturated ketones. Can J Pharm Sci 1976;11: 35-53. 